\title{
Front Matter: Volume 10502
}

, "Front Matter: Volume 10502," Proc. SPIE 10502, Adaptive Optics and Wavefront Control for Biological Systems IV, 1050201 (20 March 2018); doi: $10.1117 / 12.2323029$

SPIE. Event: SPIE BiOS, 2018, San Francisco, California, United States 


\title{
Adaptive Optics and Wavefront Control for Biological Systems IV
}

\author{
Thomas G. Bifano \\ Joel Kubby \\ Sylvain Gigan \\ Editors
}

27-29 January 2018

San Francisco, California, United States

Sponsored and Published by

SPIE 
The papers in this volume were part of the technical conference cited on the cover and title page. Papers were selected and subject to review by the editors and conference program committee. Some conference presentations may not be available for publication. Additional papers and presentation recordings may be available online in the SPIE Digital Library at SPIEDigitalLibrary.org.

The papers reflect the work and thoughts of the authors and are published herein as submitted. The publisher is not responsible for the validity of the information or for any outcomes resulting from reliance thereon.

Please use the following format to cite material from these proceedings:

Author(s), "Title of Paper," in Adaptive Optics and Wavefront Control for Biological Systems IV, edited by Thomas G. Bifano, Joel Kubby, Sylvain Gigan, Proceedings of SPIE Vol. 10502 (SPIE, Bellingham, WA, 2018) Seven-digit Article CID Number.

ISSN: 1605-7422

ISSN: $2410-9045$ (electronic)

ISBN: 9781510614895

ISBN: 9781510614901 (electronic)

Published by

SPIE

P.O. Box 10, Bellingham, Washington 98227-0010 USA

Telephone +1 3606763290 (Pacific Time) · Fax +1 3606471445

SPIE.org

Copyright @ 2018 , Society of Photo-Optical Instrumentation Engineers.

Copying of material in this book for internal or personal use, or for the internal or personal use of specific clients, beyond the fair use provisions granted by the U.S. Copyright Law is authorized by SPIE subject to payment of copying fees. The Transactional Reporting Service base fee for this volume is $\$ 18.00$ per article (or portion thereof), which should be paid directly to the Copyright Clearance Center (CCC), 222 Rosewood Drive, Danvers, MA 01923. Payment may also be made electronically through CCC Online at copyright.com. Other copying for republication, resale, advertising or promotion, or any form of systematic or multiple reproduction of any material in this book is prohibited except with permission in writing from the publisher. The CCC fee code is 1605$7422 / 18 / \$ 18.00$.

Printed in the United States of America.

Publication of record for individual papers is online in the SPIE Digital Library.

\section{SPIE. DIGITAL \\ SPIEDigitalLibrary.org}

Paper Numbering: Proceedings of SPIE follow an e-First publication model. A unique citation identifier (CID) number is assigned to each article at the time of publication. Utilization of CIDs allows articles to be fully citable as soon as they are published online, and connects the same identifier to all online and print versions of the publication. SPIE uses a seven-digit CID article numbering system structured as follows:

- The first five digits correspond to the SPIE volume number.

- The last two digits indicate publication order within the volume using a Base 36 numbering system employing both numerals and letters. These two-number sets start with $00,01,02,03$, 04, 05, 06, 07, 08, 09, OA, OB ... 0Z, followed by 10-1Z, 20-2Z, etc. The CID Number appears on each page of the manuscript. 


\title{
Contents
}

\author{
$\checkmark$ Authors \\ vii Conference Committee \\ ix Introduction
}

WAVEFRONT SHAPING DEVICES: DEFORMABLE MIRRORS, SPATIAL LIGHT MODULATORS

1050203 Rapid and highly integrated FPGA-based Shack-Hartmann wavefront sensor for adaptive optics system [10502-2]

1050204 Advanced SLMs for microscopy [10502-3]

AO FOR MICROSCOPY AND OPTICAL COHERENCE TOMOGRAPHY I

1050206 Sensorless adaptive optics for isoSTED nanoscopy (Invited Paper) [10502-5]

1050209 Robust adaptive optics systems for vision science (Invited Paper) [10502-8]

AO FOR MICROSCOPY AND OPTICAL COHERENCE TOMOGRAPHY II

10502 OB Scene-based Shack-Hartmann wavefront sensor for light-sheet microscopy [10502-10]

10502 OE Conjugate adaptive optics with remote focusing in multiphoton microscopy (Invited Paper) [10502-13]

AO FOR MICROSCOPY AND OPTICAL COHERENCE TOMOGRAPHY III

10502 0J Measurement of wavefront aberrations in cortex and peripheral nerve using a two-photon excitation guidestar [10502-58]

FOCUSING LIGHT THROUGH SCATTERING TISSUES: OPTIMIZATION, TRANSMISSION MATRIX I

10502 ON Swiftly moving focus points and forming shapes through the scattering media [10502-21] 
FOCUSING LIGHT THROUGH SCATTERING TISSUES: OPTIMIZATION, TRANSMISSION MATRIX II

$105020 Q \quad$ Wavefront shaping to correct intraocular scattering [10502-24]

COMPUTATIONAL OPTICAL IMAGING TECHNIQUES

10502 OW Imaging through scattering media by Fourier filtering and single-pixel detection [10502-31]

APPLICATIONS OF TIME-REVERSAL IN BIOLOGICAL IMAGING, OPTICAL PHASE CONJUGATION

1050210 Time-reversed ultrasonically encoded (TRUE) focusing for deep-tissue optogenetic modulation [10502-35]

SHAPED BEAMS FOR LIGHT SHEET AND STRUCTURED ILLUMINATION MICROSCOPY

1050211 Adaptive optics improves multiphoton super-resolution imaging (Invited Paper) [10502-36]

1050212 Hybrid adaptive and computational light-sheet fluorescence microscopy [10502-37]

CHANNEL DEMIXING FOR ENDOSCOPY/FIBERS II

10502 1B Wavefront shaping for ultrashort pulse delivery through optical fibers for imaging and ablation [10502-46]

POSTER SESSION

10502 1F Practical guidelines for implementing adaptive optics in fluorescence microscopy [10502-51]

$105021 \mathrm{H} \quad$ High quality adaptive optics zoom with adaptive lenses [10502-53] 


\section{Authors}

Numbers in the index correspond to the last two digits of the seven-digit citation identifier (CID) article numbering system used in Proceedings of SPIE. The first five digits reflect the volume number. Base 36 numbering is employed for the last two digits and indicates the order of articles within the volume. Numbers start with 00, 01, 02, 03, 04, 05, 06, 07, 08, 09, 0A, OB...0Z, followed by 10-1Z, 20-2Z, etc.

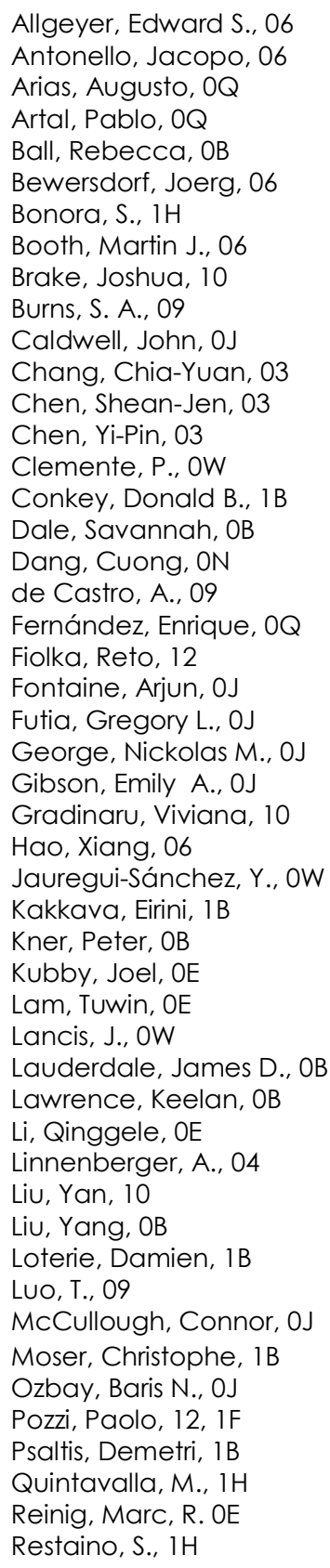


Proc. of SPIE Vol. 10502 1050201-6

Downloaded From: https://www.spiedigitallibrary.org/conference-proceedings-of-spie on 26 Apr 2023 Terms of Use: https://www.spiedigitallibrary.org/terms-of-use 


\title{
Conference Committee
}

\author{
Symposium Chairs
}

James G. Fujimoto, Massachusetts Institute of Technology

(United States)

R. Rox Anderson, Wellman Center for Photomedicine, Massachusetts General Hospital (United States) and Harvard Medical School

(United States)

Program Track Chairs

Ammasi Periasamy, University of Virginia (United States)

Daniel L. Farkas, University of Southern California (United States) and SMI (United States)

\section{Conference Chairs}

Thomas G. Bifano, Boston University (United States)

Joel Kubby, University of California, Santa Cruz (United States)

Sylvain Gigan, Laboratoire Kastler Brossel (France)

\section{Conference Program Committee}

Jacopo Bertolotti, University of Exeter (United Kingdom)

Martin J. Booth, University of Oxford (United Kingdom)

Wonshik Choi, Korea University (Korea, Republic of)

Meng Cui, Purdue University (United States)

John M. Girkin, Durham University (United Kingdom)

$\mathrm{Na} \mathrm{Ji}$, University of California, Berkeley (United States)

Benjamin Judkewitz, Charité Universitätsmedizin Berlin (Germany)

Ori Katz, The Hebrew University of Jerusalem (Israel)

Peter A. Kner, The University of Georgia (United States)

Pablo Loza-Alvarez, ICFO - Institut de Ciències Fotòniques (Spain)

Allard P. Mosk, Utrecht University (Netherlands)

Rafael Piestun, University of Colorado at Boulder (United States)

Laura Waller, University of California, Berkeley (United States)

Monika Ritsch-Marte, Medizinische Universität Innsbruck (Austria)

\section{Session Chairs}

1 Wavefront Shaping Devices: Deformable Mirrors, Spatial Light Modulators

Thomas G. Bifano, Boston University (United States) 
2 AO for Microscopy and Optical Coherence Tomography I

Martin J. Booth, University of Oxford (United Kingdom)

3 AO for Microscopy and Optical Coherence Tomography II John Girkin, Durham University (United Kingdom)

4 AO for Microscopy and Optical Coherence Tomography III Peter Kner, The University of Georgia (United States)

5 Focusing Light Through Scattering Tissues: Optimization, Transmission Matrix I

Sylvain Gigan, Laboratoire Kastler Brossel (France)

6 Focusing Light Through Scattering Tissues: Optimization, Transmission Matrix II

Rafael Piestun, University of Colorado Boulder (United States)

7 Computational Optical Imaging Techniques

Na Ji, University of California, Berkeley (United States)

8 Applications of Time-Reversal in Biological Imaging, Optical Phase Conjugation

Changhuei Yang, California Institute of Technology (United States)

9 Shaped Beams for Light Sheet and Structured Illumination Microscopy

Monika Ritsch-Marte, Medizinische Universität Innsbruck (Austria)

10 Channel Demixing for Endoscopy/Fibers I

Tomáš Čižmár, University of Dundee (United Kingdom)

11 Channel Demixing for Endoscopy/Fibers II

Kayvan F. Tehrani, The University of Georgia (United States) 


\section{Introduction}

High-resolution imaging of biological systems often requires adaptive optics and/or wavefront control to overcome the adverse impact of aberrations and scattering. Tools and techniques described in this conference series have catalyzed new capabilities in biological microscopy and biophotonic sensing, especially by improving resolution, imaging depth, or field of view. Applications enabled by new light-shaping technologies include deep tissue nonlinear microscopy, optical coherence tomography (OCT), retinal imaging, structured illumination imaging, endoscopy, and focusing light through dynamic diffusive media. The conference highlights emerging approaches to microscopy and endoscopy that are based on wavefront control, light shaping, time reversal, phase conjugation, adaptive optics, and transmission matrix optimization. It also serves as a forum for describing new developments and characteristics of deformable mirrors and wavefront controllers, and their use with new algorithms and techniques that can control or modify light transmission through or in complex media.

We would like to thank all of the authors who contributed to this conference.

\section{Thomas G. Bifano Joel Kubby Silvain Gigan}


Proc. of SPIE Vol. 10502 1050201-10 Downloaded From: https://www.spiedigitallibrary.org/conference-proceedings-of-spie on 26 Apr 2023
Terms of Use: https://www.spiedigitallibrary.org/terms-of-use 